\title{
FLOOD ESTIMATION OF SARDA RIVER USING WAKEBY DISTRIBUTION IN CHAMPAWAT DISTRICT, UTTRAKHAND
}

\author{
Kiran Rani \\ Student of Civil Engineering \\ G.B.P.U.A.T, Pantnagar, Uttrakhand, India
}

\begin{abstract}
The Wakeby probability distribution function was applied to estimate extreme flood discharges associated to different return periods with 86 years length of the data in Champawat district of Uttrakhand. This distribution had advantages over other probability distributions because its parameters were found using the probability weighted moments that represent in linear trend the characteristics of present data. Wakeby distribution was a five parameters distribution used more than the other distributions reason for which was that it can attain wider range of distributional shapes as other ones. This study indicated that wakeby five parameter distributions used for analyzing the maximum annual discharge for the present study area. In this study we described the procedure to estimate the Wakeby distribution parameters for analysis of Sarda river discharge.
\end{abstract}

Keywords - Flood frequency analysis, wakeby probability distribution, growth factors

\section{INTRODUCTION}

In Hydraulic engineering since more than thirty years design of flood frequency analysis using statistical approaches has become one of the robust and active field of application in research work in water resource engineering. Frequency analysis is the method of estimation which specified us how an event will occur. If the different observed quantities have the similar event frequencies in this case more accurate conclusion we can get by analyzing the all data sample together. In the environmental applications this method is called as regional frequency analysis. The reason of it is that within particular region for measuring the same variable a number of observations are analyzed from a number of sites.

\section{STUDY AREA AND DATA AVAILABILITY}

The Sarda River originates from the Greater Himalayas at Kalapaani, at an altitude of $3600 \mathrm{~m}$, in the Champawat District of Uttarakhand. The river borders the Nepalese Mahakali Zone and the Indian state of Uttarakhand. Mahakali flows for a

\author{
Mrs Jyothi Prasad \\ Prof. of Civil Engineering \\ G.B.P.U.A.T, Pantnagar, Uttrakhand, India
}

length of $223 \mathrm{~km}$ length in Nepal and $323.5 \mathrm{~km}$ in India up to its confluence with Ghaghra River.

Sarda, a major tributary of Ghaghara River pierces through the Siwalik Hills and emerges into the Ganga Plain in the vicinity of Tanakpur in the Champawat district of Uttrakhand (as shown in figure).

The maximum annual rainfall data of 86 years provided from Banbsa barrage at Sarda River from (1930-2014). The existing

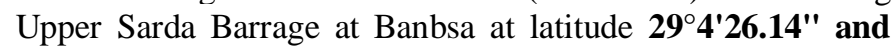
longitude $80^{\circ} \mathbf{7}^{\prime} 10.61^{\prime \prime}$

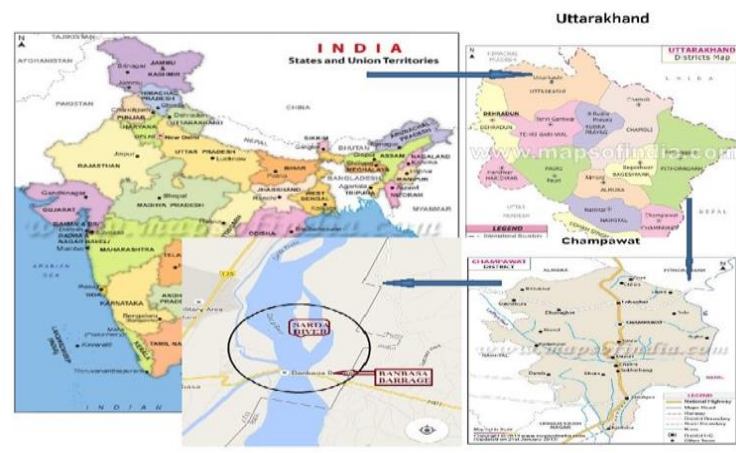

Fig1: Location Map of Banbsa Barrage

\section{METHODS AND MATERIAL}

\section{Wakeby distribution}

Wakeby distribution was a five parameters distribution used more than the other distributions reason for which was that it can attain wider range of distributional shapes as other ones. Inverse form Wakeby (WAK) distribution was expressed as:

$x(F)=\xi+\frac{\alpha}{\beta}\left\{1-(1-F)^{\beta}\right\}-\frac{\gamma}{\delta}\{1-(1-F)-\delta\}$

Where, $\xi, \alpha, \beta, \gamma$, and $\delta$ are the parameters of the Wakeby distribution. 
International Journal of Engineering Applied Sciences and Technology, 2020

Vol. 5, Issue 3, ISSN No. 2455-2143, Pages 331-334

Published Online July 2020 in IJEAST (http://www.ijeast.com)

\section{RESULTS AND DISCUSSION}

\section{Estimated of Parameters for wakeby distribution}

Wakeby distribution was a five parameters distribution used more than the other distributions reason for which was that it can attain wider range of distributional shapes as other ones. The estimated parameters of wake by distribution are given below in Table No 1.

\begin{tabular}{|c|c|c|c|c|c|}
\hline Distribution & \multicolumn{5}{|c|}{ Parameters of the distribution } \\
\hline & & & & & \\
\hline WAK & $\zeta=0.41$ & $\alpha=1.110$ & $\beta=1.307$ & $\gamma=0.081$ & $\delta=0.243$ \\
\hline
\end{tabular}

The values obtained in the Table no. 1 such as location parameter 0.41 and $\alpha=1.110$, Scale parameter $\beta=1.307, \gamma=$ 0.081 and $\delta=0.243$ parameters of Wakeby distributions, further used for estimating the design discharge value for annual maximum discharge of Sarda River.

Estimation of growth factors $\left(Q_{\mathrm{T}} / \overline{\mathrm{Q}}\right)$ for wake by distribution

Table 3 shows the growth factor varies for 2 years is 0.979 to 1000 return period as 2.7141 . For estimating the quantile function using most suitable distribution for various return periods such as $2,10,50,100,200,500$ and for 1000 years or multiplying the each growth factor with mean value of annual maximum discharge $(\overline{\mathrm{Q}})$ are given in Table 2 .

Table 2: Values of the growth factors $\left(\mathrm{Q}_{\mathrm{T}} / \overline{\mathrm{Q}}\right)$ for wake by distribution

\begin{tabular}{|c|c|c|c|c|c|c|c|c|}
\hline $\begin{array}{c}\text { Distribu- } \\
\text { tion }\end{array}$ & \multicolumn{7}{|c|}{ Return period (Years) } \\
\hline & 2 & 10 & 25 & 50 & 100 & 200 & 500 & 1000 \\
& & & & & & & & \\
& \multicolumn{8}{|c|}{ Growth factors } \\
\hline WAK & 0.979 & $\begin{array}{c}1.46 \\
9\end{array}$ & $\begin{array}{c}1.64 \\
4\end{array}$ & $\begin{array}{c}1.78 \\
5\end{array}$ & $\begin{array}{c}1.94 \\
7\end{array}$ & $\begin{array}{c}2.13 \\
5\end{array}$ & $\begin{array}{c}2.43 \\
7\end{array}$ & $\begin{array}{c}2.71 \\
4\end{array}$ \\
& & & & & & & & \\
\hline
\end{tabular}

Table 3: Design Values of Maximum Discharge Using Growth Factors

\begin{tabular}{|c|c|c|}
\hline $\begin{array}{c}\text { Return } \\
\text { period }\end{array}$ & Growth factors & $\begin{array}{c}\text { Maximum discharge= } \\
\text { Growth factor*mean(7906.3) } \\
\mathbf{m}^{\mathbf{3}} / \mathbf{s}\end{array}$ \\
\hline 2 & 0.979 & 7740.268 \\
\hline 10 & 1.469 & 11614.350 \\
\hline 25 & 1.644 & 12997.960 \\
\hline 50 & 1.785 & 14112.750 \\
\hline 100 & 1.947 & 15393.570 \\
\hline 200 & 2.135 & 16879.950 \\
\hline 500 & 2.437 & 19267.650 \\
\hline 1000 & 2.714 & 21457.700 \\
\hline & & \\
\hline
\end{tabular}

It was found that the discharge vary for 2 years as $7740.268 \mathrm{~m}^{3} / \mathrm{sec}$ and for 1000 year return period $21457.7 \mathrm{~m}^{3} / \mathrm{sec}$ are shown in Table 4.

Table 4: Floods of various return periods estimated using Wake by Distribution

\begin{tabular}{|c|c|c|}
\hline S. No. & Return period (years) & Flood in $\left(\mathbf{m}^{\mathbf{3}} / \mathbf{s}\right)$ \\
\hline 1 & 2 & 7740.268 \\
\hline 2 & 10 & 11614.350 \\
\hline 3 & 25 & 12997.960 \\
\hline 4 & 50 & 14112.750 \\
\hline 5 & 100 & 15393.570 \\
\hline 6 & 200 & 16879.950 \\
\hline 7 & 500 & 19267.650 \\
\hline 8 & 1000 & 21457.700 \\
\hline
\end{tabular}


International Journal of Engineering Applied Sciences and Technology, 2020

Vol. 5, Issue 3, ISSN No. 2455-2143, Pages 331-334

Published Online July 2020 in IJEAST (http://www.ijeast.com)

\section{GRAPHICAL REPRESENTATIONS}

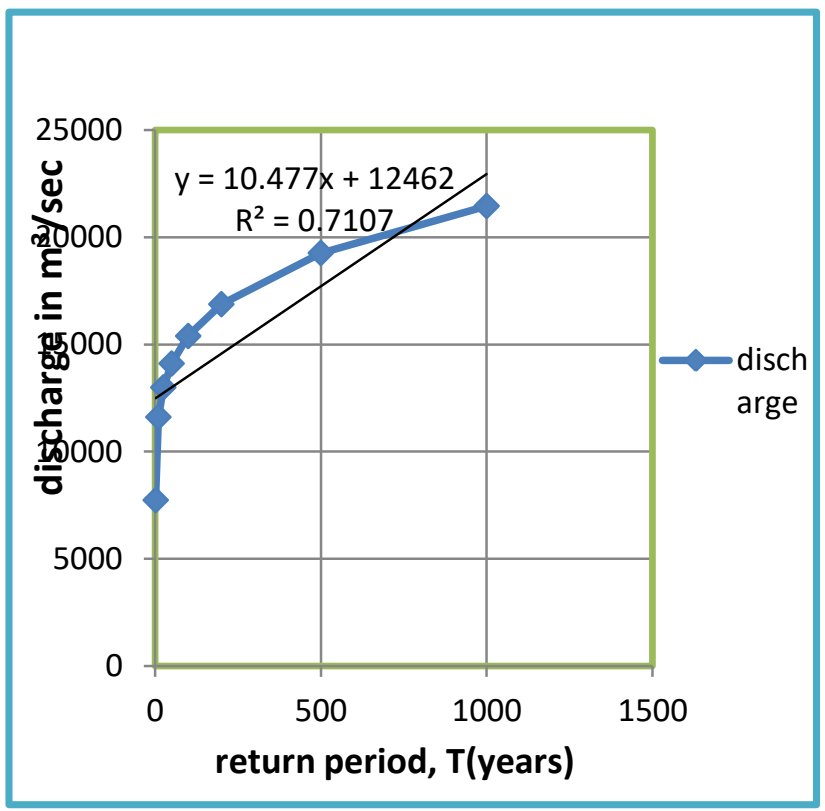

Fig2: Plot of predicted discharge vs. return period

Fig2 shown a graphical representation between design discharge and return period, discharge vs. Non- exceedence probability.

Figure. 2 shown trend line equation between discharge and coefficient of determination $\mathrm{R}^{2}=0.7107$ and figure 3 shown the relation between discharge and probability of non exceedence and coefficient of determination $\mathrm{R}^{2}=0.5877$ lies between the expected value for coefficient of determination (between 0 to1).

Hence for predicting expected flow in Sarda River the Wakeby is the best suitable distribution.

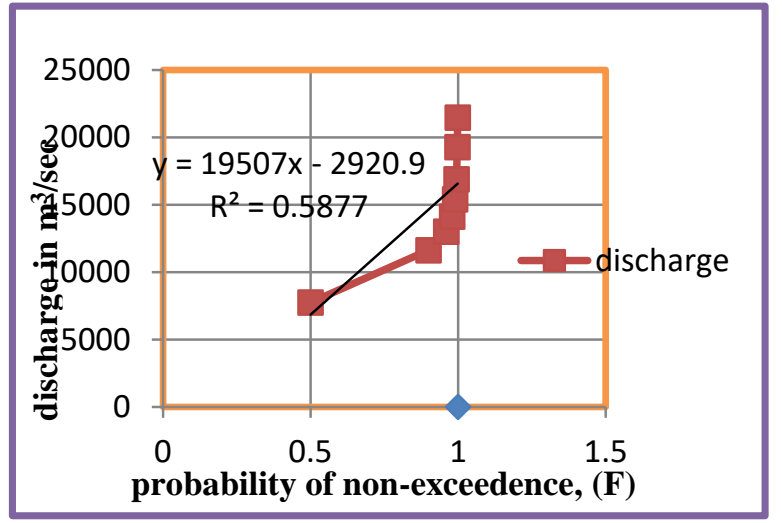

Fig3: Plot of predicted discharge vs. non exceedence probability

\section{SCOPE FOR FURTHER STUDY}

1.The present study has taken up only one site of Sarda river Catchment area hence for regionalization more gauging sites data need to be studied.

2. The wakeby probability distribution further can be used for estimates the design values of discharge which are useful for design hydraulic structures such as, canals, irrigation ditches, dam and other hydrologic studies.

3. Measuring the density of gauging network for a river basin which provides the possibility of planning and development water resources for a country.

4. More number of distributions needs to be applied so that proper recommendations may be given for use of distributions.

5. The study has a good application in flood hazard mapping of any region. The results presented in this study need to be revised by including more stations with additional data lengths.

\section{CONCLUSION}

In this study 86 years maximum annual discharge data for single site (Sarda river maximum discharge at Banbsa barrage) analyzed using wakeby five parameter distribution was the best fit for study the annual maximum discharge of Sarda River.

\section{ACKNOWLEDGEMENT}

The authors are grateful to Mr. Yogendra Sain, Technical Assistant in Agriculture, Tehsil Rampur Maniharan (Saharanpur district) for his support and help in data collection.

\section{REFERENCES}

[1] Dalrymple .T (1960), "flood frequency analysis", Water Supply Paper, 1543. A US Geological, Survey, Reston Virginia.

[2] Greenwood et al. (1979), "Probability weighted moments: Definition and relation to parameters of several distributions expressible in inverse form". Water Resources Research, 15, 1049-1054.

[3] Cunnane C (1989), "Statistical distributions for flood frequency analysis", W.M.O. No.718, Operational Hydrology Report No. 33, Geneva.

[4] Boes et al. (1989), "Regional flood quantile estimation for a Weibull model", Water Resources. Res. 25(5): 979-990. 
[5] Hosking JRM (1990), "L - moments: analysis and estimation of distribution using linear combination of order statistic". J Royal Stat Soc B 52:105-124.

[6] Vogel RM, Fennessey (1993), "L-Moments should replace Product Moments Diagrams". Water Resource, Res 29(6):1745-1752.

[7] Hosking JRM, Wallis (1993)," Some statistics useful in regional frequency analysis". Water Resource Res 29(2): 271-281.

[8] Hosking JRM, Wallis (1997), “ Regional Flood Frequency Analysis an Approach Based On LMoment", Cambridge University Press, N.Y

[9] Rakesh Kumar, C Chatterjee (2005), "Regional Flood Frequency Analysis Using L-Moments for North Brahmaputra Region of India”. Journal of hydrologic engineering February 2005.

[10] Ramin Rostami (2013), "Iran Regional Flood Frequency Analysis Based on L-Moment Approach (Case Study West Azarbayjan Basins)". Journal of Civil Engineering and Urbanism, Miandoab, India. Volume 3.

[11] Amit Dubey (2014) "Regional Flood Frequency Analysis Utilizing L-Moments: A Case Study of Narmada Basin", S.G.S.I.T.S, Indore.

[12] Gbadebo and Adesiji Richard (2014), "Flood Frequency Analysis of River Bako, Niger State, Nigeria", International Journal Engineering research and technology, Nigeria, ISSN: 2278-0181.
[13]H. Malekinezhad (2014), “ Yazd University, Yazd, Islamic republic of Iran, journal of agriculture and science technology, Volume13:1183-1196

[14] .Abhijit Bhuyan (2015), "Rainfall frequency analysis of north east India", International Conference on Frontiers in Mathematics “, 2015 March 26-28, 2015, Guwahati, Assam, India.

[15] Ataur Rehman et al. (2015), "Applicability of Wakeby distribution in flood frequency Analysis: a case study for eastern Australia”. Hydrol. Process. 29602-614. 